\title{
Informação pandémica e capitalismo viral: a mídia, a Covid-19 e a construção dos medos
}

\author{
Pandemic information and viral Capitalism: media, Covid-19 and \\ the construction of fears
}

\begin{abstract}
Giulia Crippa ${ }^{a}$ **
RESUMO: O artigo observa a construção das narrativas relativas à pandemia pelo novo coronavírus, a partir de títulos da grande mídia e de algumas imagens das mesmas fontes, principalmente a partir de materiais produzidos no contexto italiano do desenrolar dos acontecimentos. Analisa como essas narrativas acompanham os interesses das políticas públicas e, ao mesmo tempo, dos interesses econômicos. Busca entender a mediação que foi construída com a população, no uso da linguagem e no tipo de metáforas utilizadas pela mídia presente em plataformas digitais. Define em que maneira a narrativa midiática encontrou um terreno fértil de compreensão entre a população. As fontes utilizadas foram títulos e imagens de jornais e telejornais disponíveis online. $\mathrm{O}$ artigo descreve como se desenvolveram as estratégias de manutenção do capitalismo durante a pandemia através dessas narrativas.
\end{abstract}

Palavras-chave: Pandemia; Novo Coronavírus; Covid-19; Capitalismo; Informação; Narrativas.

ABSTRACT: The article observes the construction of narratives related to the new coronavirus pandemic, based on headlines from the mainstream media and some images from the same sources, mainly from materials obtained in the Italian context of the unfolding events. It analyzes how these narratives accompany the interests of public policies and, at the same time, of economics It seeks to understand the mediation that was built with the population, through the use of language and through the type of metaphors used by the media present on digital platforms. It defines how media narratives found fertile ground of understanding among the population. The sources used were titles and images from newspapers and news available online. The article describes how capitalism maintenance strategies were developed during the pandemic through these narratives.

Keywords: Pandemic; New coronavirus, Covid-19; Capitalism; Information; Narratives.

\footnotetext{
a Programa de Pós-Graduação em Ciência da Informação, Universidade de São Paulo, São Paulo, SP, Brasil. Dipartimento di Beni Culturali, Università di Bologna, Ravenna, RA, Itália.

* Correspondência para/Correspondence to: Giulia Crippa. E-mail: giulia.crippa2@unibo.it. Dipartimento di Beni Culturali, Università di Bologna. Via degli Ariani 1. CEP: 48121. Ravenna - RA - Itália.
}

Recebido em/Received: 15/08/2020; Aprovado em/Approved: 22/12/2020.

Artigo publicado em acesso aberto sob licença CC BY 4.0 Internacional (C)( 


\title{
INTRODUÇÃO
}

O evento inesperado e rápido da pandemia provocada pelo novo coronavírus pegou todos despreparados. Os parâmetros dentre os quais foram produzidos e trocados dados científicos estão totalmente fora de escala, da mesma maneira que as análises socioeconômicas têm sido produzidas, também, de maneira atípica circulando principalmente nas redes sociais, por meio de links a inúmeros sites que disponibilizaram textos e reflexões de intelectuais reconhecidos globalmente. Como escrever um artigo que indague a circulação de imagens de um acontecimento de porte global ainda em andamento, qual é o caso da pandemia pelo novo coronavírus, cuja doença foi batizada, pela Organização Mundial da Saúde (OMS), como covid-19 (COronaVIrus Disease 2019), considerando que os repertórios da memória relativos a eventos dessa natureza, ainda que presentes, referem-se em sua grande maioria, a eventos anteriores à invenção dos jornais (como a peste que assolou a Europa no século XVII) ou, quando mais recentes, referem-se a eventos bem anteriores aos atuais conhecimentos médicos. Principalmente, como indagar as formas de circulação e apropriação das informações veiculadas pelos jornais online, considerando que se trata de uma informação destinada a um público em grande parte não especializado no campo científico, mas que precisa de um imaginário, de narrativas através das quais regulem seus comportamentos durante uma emergência planetária como a que estamos vivendo.

No quadro de produção e circulação de informações, solicitadas por uma emergência inédita para todas as áreas, grandes destaques foram dados à medicina e à biologia para o estudo do coronavírus, de suas patologias, de sua natureza e configuração genética; à química, para a busca de remédios para os sintomas; à física e à engenharia, envolvidas com os sistemas de ventilação pulmonar, mas também para explicar ao grande público como temperatura, ventilação, umidade e outros fatores físicos aumentam ou reduzem o contágio pelo coronavírus. Perante tudo isso, a troca de dados acelerada entre centros de pesquisas e universidades têm descartado, com frequência, a publicação em revistas de alto impacto científico e arbitragem rigorosa em favor de modalidades menos intermediadas, como repositórios abertos ou trocas diretas: o tempo entre a submissão de um artigo e seu parecer tornou-se demasiado longa, nas condições postas por uma pandemia.

\section{Como claramente expõe Andrea Meneganzin (2020),}

\begin{abstract}
As pandemias não esperam a peer-review. O processo de "revisão entre pares" - passagem obrigatória de todo pesquisador que queira ver sua própria pesquisa publicada em uma revista científica, e que acarreta várias rodadas de revisão e integração do manuscrito original, antes de sua validação definitiva por parte dos revisores e do editor [...] - requer vários meses e, com frequência, precisa de um ano. A revisão paritária das publicações científicas é uma forma de controle da qualidade dos resultados produzidos e de autocrítica interna da comunidade científica, mas é um processo trabalhoso e caro, também em termos econômicos: nas mais prestigiosas e seletivas revistas de acesso aberto (open access) os custos de publicação alcançam os três dígitos.

Mesmo quando os artigos são submetidos às revistas com peerreview, os tempos de avaliação caíram de meses para 24/48 horas (MENEGANZIN, 2020).
\end{abstract}

Falamos, porém, que a produção informacional acadêmica "fora do padrão" entendendo, com isso, informações que não seguiram os caminhos acadêmicos 
costumeiros de avaliação das revistas, mas que foram produzidas e divulgadas através de sites e plataformas não necessariamente especializados em produção científica tem alcançado todas as áreas de pesquisa, não somente aquelas mais claramente focadas no "combate" biofísico à pandemia. De fato, uma grande mobilização por parte dos intelectuais ligados à filosofia, à sociologia, à história e aos estudos literários e culturais - para nos acompanhar nos longos meses de lockdown e outras formas de distanciamentos entre corpos, têm oferecido uma farta provisão de registros sobre os imaginários pan/epidêmico sobre as pragas, sobre doenças apocalíticas tanto na literatura como no cinema.

O alcance de textos produzidos por intelectuais conhecidos foi ampliado, não somente pela mídia tradicional, como também, em boa parte, pelo uso direto das mídias sociais que, elas sim, tornaram-se mediadoras desses textos. Todavia, o que queremos apontar é que, no campo das ciências humanas e sociais, também se assiste à redução das barreiras constituídas pelas formas acadêmicas de seleção dos artigos pelo rigor da revisão. Essas questões jogam uma luz sobre a natureza das referências que precisamos utilizar no quadro de um acontecimento em que as mudanças na esfera da informação se manifestaram.

Complexo é distinguir, dessa maneira, o que é um referencial teórico-metodológico de um trabalho como o que nos propomos a fazer aqui: de fato, os referenciais produzidos pelos pensadores que envergam os trabalhos acadêmicos, enquanto os colocamos como estacas para nosso ponto de partida no olhar que jogamos sobre algum fenômeno, tornam-se instáveis, na medida em que são, agora, parte do próprio fenômeno. Eles participam da pandemia em tempo real, sem a possibilidade reflexiva que os tempos de produção acadêmica proporcionam. Emergência impõe ritmos e objetos de análise que se projetam no curto prazo e que esbarram no desconhecimento sobre os resultados dos fenômenos. Ninguém sabe os desdobramentos da pandemia. Navegamos à vista, e isso produz esse curioso efeito de lermos análises que um dia fazem sentido e que, nas semanas seguintes, se revelam falhas e devem ser reformuladas. Como a dizer: estamos tateando, escrevendo crônicas, tentando os primeiros esboços a partir do que conhecíamos, mas tudo muda rapidamente e essa experiência não está no controle de um "laboratório". É acontecimento em andamento, tão extenso em seus efeitos que qualquer resultado de pesquisa que arrisca ser conclusivo é, inevitavelmente, bastante provisório.

Basta pensar no exemplo de um breve artigo de Giorgio Agamben, publicado no quotidiano II Manifesto. Em 25 de Fevereiro de 2020, o filósofo escreve, em um jornal declaradamente de esquerda, considerações sobre as medidas de controle excepcionais tomadas pelo Governo italiano. Afirma que a doença é altamente contagiosa, mas com baixa letalidade. Afirma que está se configurando um "Estado de Exceção" destinado a dar uma guinada autoritária e de controle invasivo por parte do Estado. Afirma que as liberdades democráticas estão em risco. Para suas afirmações, o filósofo se fundamenta em materiais fornecidos pelo Conselho Nacional de Pesquisas $(C N R)$, organismo institucional ligado às políticas de pesquisa governamentais (AGAMBEN, 2020).

Dez dias depois, no dia 11 de março, a Itália inteira entrou em um estado de lockdown total. Mal podia imaginar, Agamben, que, no curto prazo de três semanas do artigo que redigiu no mais profundo espírito libertário, teríamos as imagens dos caminhões do Exército transportando, em longa coluna, os caixões chumbados das vítimas de covid-19, saindo do hospital de Bergamo para serem cremados em outras cidades: 0 forno crematório da cidade estava superlotado. Imagens que circularam pelas mídias tradicionais e pelas mídias sociais do mundo inteiro. Uma situação que não podia ser 
narrada da mesma maneira das conhecidas. Não há precedentes para o que aconteceu e o que está acontecendo. Uma pandemia dessa natureza precisou encontrar seus antepassados em vários momentos da história: a gripe espanhola, e os resultados do enfrentamento que houve na época eram desalentadores, considerando que, na época, havia ainda uma guerra em andamento. Enfim, perante a disseminação exponencial dos contágios, tornou-se necessário construir narrativas que permitissem que a população se apropriasse, em tempos muito rápidos, de alguns conceitos chave, elaborando-os de maneira que passasse a agir conformando-se às políticas emergenciais.

Dessa maneira, o que pretendemos, nesse texto, é percorrer o conjunto das narrativas construídas em um período que vai de março de 2020 e que chega até junho, quando a maioria das medidas excepcionais acabaram em todas as regiões da Itália. Esse conjunto de narrativas é oferecido através da análise de títulos e imagens (fotos e vídeos) relativos à informação quotidiana para o grande público pelos sites de jornais e instituições, a partir da decisão política do Estado italiano de decretar uma fase de lockdown para "estancar" o ritmo dos contágios, no dia 11 de março. O trabalho não entra, necessariamente, no mérito da veracidade das notícias, nem pretende verificar o valor dos estudos ou dos cientistas citados. O que pretendemos observar é de que maneira um conjunto de políticas se relaciona com as linguagens e modalidades de circulação na mídia.

Que uso da linguagem, que metáforas a mídia tradicional, presente também em plataformas digitais encontrou, para construir narrativas sobre o novo coronavírus e sobre a covid-19? De que maneira a narrativa midiática encontrou um terreno fértil de compreensão entre a população?

Boa parte de nossas reflexões, portanto, é constituída por títulos de jornais e por algumas fotos e vídeos presentes em suas plataformas digitais. Buscamos elaborar uma reflexão sobre as narrativas construídas, em um quadro em que o conteúdo analisado, como signo, linguagem, discurso informacional é ideologicamente entrelaçado com as esferas da política e da economia.

O princípio que norteia nosso trabalho, portanto, é que manchetes, fotos e vídeos, além das escolhas e intenções de seus autores, não são neutros, correspondendo a ideologias, políticas e visões do mundo, tornando-se funcionais nas estratégias de mediação voltadas para a elaboração, a estruturação e a desestruturação dessas mesmas narrativas.

Por se tratar de uma investigação ligada à construção de um imaginário pandêmico, é importante explicitar alguns conceitos teóricos aos quais aderimos, já que o repertório de imagens é oferecido como exemplo de índice de processos simbólicos, ideológicos e representativos. A relação das imagens com o campo do imaginário já foi objeto de ampla discussão para Le Goff (1993), e é a partir de sua proposta que observamos as notícias como representações da pandemia, da doença e de como enfrentá-las, Entre permanências e transformações - lembrando Durand (2012), segundo a qual crenças coletivas não são substituídas se uma sociedade não consegue criar novas - as imagens revelam aquele espaço no qual a ideologia, como relação social, entra na esfera do imaginário na relação que este estabelece com a realidade.

Novamente partindo da obra de Durand (2012), o artigo visa oferecer a polissemia de imagens portadoras do mesmo símbolo; observar suas elaborações, para compreender como são capazes de explicar sua apropriação e "reuso" heterogêneo no tempo e no espaço e, por fim, a difusão dos temas simbólicos oferecidos às apropriações socioculturais. 
O trabalho será norteado principalmente pelas notícias relativas à Itália, por duas razões:

a) É o lugar de vivência da autora, que se encontrou sem mobilidade nesse país durante o lockdown.

b) Foi o primeiro país na Europa e no Ocidente a se encontrar na obrigação de tomar decisões extremamente graves e com consequências de grande peso na sociedade e na economia perante uma emergência sanitária de porte desconhecido até agora.

Por se tratar de reflexões que não comportam um resultado definitivo, nem pretendem considerar um conjunto exaustivo de dados, propomos a leitura do texto como ensaio, considerando a situação atual como um ponto em um tempo ainda não determinado, no qual certezas e linearidades nem sempre podem ser respeitadas.

\section{ALGUMAS PRIMEIRAS REFLEXÕES}

No quadro temporal que vai de março a junho de 2020, analisamos o entrelaçamento entre políticas entendidas como

a) governo do Estado e seus aparatos,

b) gestão da economia

c) seleção das notícias de necessidade pública a serem mediadas para a população via mídias de grande alcance, isso é: jornais, rádio e televisão, mídia social.

É preciso colocar algumas questões, para discutir o que resolvemos chamar de Capitalismo Viral (CV).

A pandemia destacou alguns aspectos críticos nas estruturas da sociedade capitalista de hoje. Os Jogos Olímpicos, embora com relutância, foram adiados para 2021. As principais economias capitalistas foram ofuscadas pelo vírus, forçando escolhas sem precedentes até o momento.

Segundo um dos pais do neoliberalismo, Von Hayek (1960), que escreveu na Áustria na década de 1930, o ser humano é, basicamente, racional e competitivo que persegue seu interesse individual, capaz de planejar e prever cenários que lhe permitem concretizar seus interesses. Para ele e para seus seguidores, a realização do homo economicus se encontra maximizada no mercado da demanda e oferta, onde pode se desenvolver na plenitude da liberdade. O mecanismo faz com que a concorrência o leve em frente, com o desejo de despontar e possuir mais que os outros. Em tudo isso, o efeito para a sociedade deveria ser a obtenção dos produtos melhores e mais econômicos. O que é bom para o mercado, para os neoliberais, é bom para a humanidade, para a sociedade. O mercado sabe o que precisa melhor que as instituições políticas, pois o que é inútil, na medida que não vende, desaparece. Para a doutrina neoliberal, o mercado é neutral, pois se fundamenta em números e, por essa concepção, seria destinado a nos livrar todos. $O$ outro lado é que esse sistema reduz tudo a matéria prima a ser explorada: a natureza, o trabalho, as pessoas.

É evidente que o egoísmo individual como motor do bem-estar global, que é a "Mão Invisível" smithiana do mercado, mostra fendas evidentes: o mercado é capaz de criar pobreza mesmo em abundância. O neoliberalismo destruiu todos os freios à ganância, o individualismo substituiu a solidariedade. Além disso, a crise em nossa sociedade não diz respeito apenas às estruturas econômicas, mas afeta a ideologia, a política, a moral, os aspetos militares, as relações com o meio ambiente. Alguns economistas, não 
apenas os nostálgicos do marxismo, estão se perguntando se as estruturas econômicas básicas de nossas sociedades capitalistas avançadas, sociedades de lucro e de mercado, podem passar por uma revisão profunda, mas ao menos que se passe para um novo tipo de organização econômica e social. Isso não aparenta ser possível.

Estamos cientes de que, como disse John Maynard Keynes, "o capitalismo não é inteligente, não é bonito, não é justo, não é virtuoso e não produz os bens necessários. Em suma, não gostamos e começamos a desprezar. Mas quando nos perguntamos o que colocar em seu lugar, ficamos extremamente perplexos. " (KEYNES, 2006, p. 21)

Não é por acaso que o historiador Donald Sasson, quando questionado se veremos o fim da globalização e do capitalismo, responde: "Acho que não. O fim do capitalismo significaria que existem alternativas, e neste momento não é o caso" (FIORI, 2020).

Sem oferecer a cronologia completa dos acontecimentos que levaram a OMS a decretar a emergência de uma pandemia global, nos limitaremos a algumas primeiras observações sobre a situação compartilhada pela maioria dos países que passam por ela. Com a pandemia provocada pelo novo coronavírus, viu-se que casos graves de infecção precisavam de terapia intensiva. Na Itália, as Unidades de Terapia Intensiva (UTIs) encontram-se, em sua grande maioria, nos hospitais públicos. O setor da saúde pública tem sofrido, nas últimas décadas, de cada vez maiores restrições orçamentárias e de reestruturações voltadas para a ampliação do setor privado. Dessa maneira, apesar de a mortalidade da infecção não ser tão alta (e, enquanto a pandemia estiver, ainda hoje, em fase ativa, a efetiva mortalidade por covid-19 permanece um dado em constante mutação), no caso de pacientes que precisavam de terapia intensiva não havia como atendê-los, na projeção da expansão do ritmo dos contágios como se desenhou no final de fevereiro de 2020. Antes de 11 de março (quando foi decretado o lockdown nacional), a transmissão do vírus foi estimada em Ro 3 em várias regiões (em que Ro indica a transmissibilidade do contágio na fase inicial da epidemia) . De 11 a 25 de março, o valor caiu em todas as áreas para valores entre Rt 0,5 e 0,7 (em que Rt representa a taxa de contágio após a tomada de medidas para conter a disseminação da infecção), que se mantiveram até o final de maio, quando a reabertura gradual provocou um leve, porém constante, incremento de ritmo de contágio, e em meados de agosto entre Rt 0,9 e 1 .

Se a infecção continuasse a se espalhar naquele ritmo, não haveria vagas suficientes nos hospitais para atender à população, em função do encolhimento do sistema de saúde pública. Uma das notícias que circularam pelas redes, em versões diferenciadas, foi da "orientação ética" a ser seguida durante a pandemia, que convidava a priorizar pacientes jovens e com melhores expectativas de vida, face à dúvida perante dois pacientes e um único leito de terapia intensiva. Corpos produtivos têm prioridade no atendimento. Notícias sobre escolhas "éticas" dessa natureza alcançaram as principais mídias nacionais tradicionais quando começaram a ser publicadas nos Estados Unidos (MOLINARI, 2020).

Necropolíticas (MBEMBE, 2018) que se tornam macropolíticas públicas, cuja complexidade vai muito além da questão da emergência. A redução da saúde pública é uma necropolítica, descobrimos com esse estranho isolamento coletivo acontecendo nas cidades. As orientações sobre os "submersos e os salvos" respondem oficialmente às modalidades dessa necropolítica. Deve-se dar prioridade aos produtivos da sociedade. Idosos e fracos não servem.

Ao lado dessa necropolítica, que nessa emergência vem sendo testada, no sentido de observar a reação da população face o "dilema" de quem salvar, se vê a biopolítica da distância. Corpos separados por pelo menos um metro nos espaços de comércio, 
enquanto os espaços de lazer, fechados, não são mais espaços para os corpos. De repente todo corpo, que não seja cada um de nós, se tornou um corpo "estranho", inimigo. Desapropriados dos lugares onde se encontravam, os corpos se isolaram no privado. $\mathrm{O}$ "outro" requer distância, o "outro" provoca distanciamento.

Os dois termos, biopolítica e necropolítica, tem conceituação teórica e se expressam, na realidade do lockdown, em sua forma mais contundente.

Segundo Foucault (2020), a partir do século XIX os estados disciplinam através do controle do corpo. Para Foucault, este não é um discurso ideológico, mas uma verdadeira "tecnologia de poder" sobre a vida e a morte, que ele define como "biopoder". O biopoder se manifesta nas estruturas que dizem respeito à saúde, transporte, segurança, higiene, e a biopolítica se manifesta nessas estruturas, inclusive estabelecendo se e como estão presentes ou ausentes. Biopolítica, assim, identifica a ação do biopoder sobre a vida e a morte de inteiras parcelas da população.

Mbembe (2018), por sua vez, aprimorando a definição de Foucault, afirma que a racionalidade ocidental pratica "a seleção das raças, a proibição dos casamentos mistos, a esterilização forçada e o extermínio dos povos derrotados" (MBEMBE, 2018, p. 19) desde a configuração do mundo colonial, bem antes do estado nazi-fascista. $O$ colonialismo é considerado, pelo autor, um espaço onde não existem normas jurídicas, para o qual a lei não pode dominar o direito de matar, e é na produção das estruturas necropolíticas primeiro raciais e, no século XX, eugenistas, que se exerce o necropoder.

O que está em jogo, portanto, é uma disputa entre princípios antagônicos, entre a vida dos corpos improdutivos ("poucos", em relação à população) e a produção de riquezas (provavelmente sempre para poucos, mas diferentes dos primeiros), e nessa disputa a vida perde, pois quem é "deficiente" não produz riquezas.

Em termos relativos, para o Capitalismo Viral, essas perdas valem a estratégia em vigor em vários países, entre os quais os Estados Unidos e o Brasil de maneira contundente. O princípio da proteção da vida retira-se para a esfera puramente privada, a morte não deve ser notícia para a comunidade, para não se tornar o motivo de um trauma coletivo. Essa lógica apresentou-se, de maneira interessante, próxima com a de Agamben (2020), no artigo já citado

Toda relação, de repente, passou a ser mediada tecnologicamente. O Capitalismo Viral tornou a crise algo "motivacional": façamos da reclusão uma ocasião de "avanço", façamos em poucos dias o que não foi feito nos últimos anos: trabalho remoto (mas é mais vendável, no mercado das ideias, chamá-lo de smartwork, isso é: trabalho "experto"), aulas "remotas", provas "remotas" para o setor da educação. A remoção dos corpos colocou em jogo novas formas de (des)confiança. A mídia, no entanto, elaborou suas narrativas entre março e maio na construção do medo através da repetição da notícia de que a Itália se encontrava no limite do crash hospitalar. Mas não houve nenhuma movimentação para "requisitar" os hospitais privados dotados de estruturas à altura das necessidades, algo que a própria Constituição italiana permite em casos de emergência. É a mesma mídia que, nas semanas anteriores ao lockdown, dizia que era tudo um grande exagero, baseando suas afirmações nas fontes fornecidas pelo CNR. Até o Prefeito de Milão, Giuseppe Sala, em 27 de fevereiro, divulgou um vídeo em suas páginas de Facebook, de propaganda sobre a "cidade que não para", retomado pela mídia nacional (AVVENIRE, 27 de fevereiro), com os dizeres: "Milão, milhões de habitantes. Fazemos milagres todo dia. Mantemos ritmos impensáveis todos os dias. Levamos para casa resultados importantes todos os dias porque todos os dias não temos medos. Milão não para", essa última afirmação antecipada por uma hashtag. Portanto, no final de fevereiro, a 
Itália se encontrou em uma encruzilhada, precisando escolher como tratar a emergência perante a população, considerando que já havia inteiras cidades consideradas "áreas vermelhas" e que o número delas se ampliava a cada dia (em 7 de março, três dias antes do lockdown nacional, as áreas vermelhas eram 14, principalmente na parte setentrional da Itália, entre Lombardia, Vêneto e Emília Romagna, três entre as regiões mais produtivas do país).

\section{METÁFORAS BÉLICAS, NECROPOLÍTICAS E OS PRINCÍPIOS ANTIFASCISTAS DE "PROTEÇÃO À VIDA": CONFLITOS}

Nas primeiras semanas da pandemia, nos títulos dos jornais se destacavam as metáforas bélicas: "guerra", "combater", "herói”, e, principalmente, "trincheira”, eram palavras recorrentes. "Na trincheira contra o vírus, eis os heróis silenciosos que combatem contra o contágio e o medo" (SECOLO XIX, 2020); "Nos hospitais estamos em guerra" (IMARISIO, 2020); "Coronavirus, reanimadores na trincheira: 'Se continuar assim, será difícil curar a todos"” (LAl, 2020); "Médicos desarmados na trincheira, assim difundimos o vírus" (ITALIANO, 2020); "O internista: na trincheira contra o vírus para ajudar minha cidade" (BOCCl, 22 de março); "Brescia na trincheira contra o vírus, aberta uma nova enfermaria com 180 leitos" (INVIATO, 2020); "Coronavirus, farmacêuticos na trincheira: 'Nós também exaustos, mas não podemos baixar a guarda"” (PEGGIO, 2020); "Os formandos na trincheira contra o vírus: 'Não nos chamem de heróis, o medo se torna coragem e amor"' (MUOLLO, 2020); "Dois meses na trincheira contra o vírus" (IL GIORNO, 2020); "Eu, médico e mãe na trincheira dupla contra a Covid" (BAZZI, 2020); "Miriam, por três meses na trincheira contra o vírus" (BELLANTE, 2020). A palavra "trincheira" remete a uma guerra de posição, lenta, desgastante (como foi a I Guerra Mundial) e não - e esse é um aspecto interessante às guerras tecnológicas às quais nos acostumamos nos últimos 30 anos, desde a Primeira Guerra do Golfo (1990-1991).

O que aconteceu foi que não estávamos conseguindo enxergar quais mutações narrativas estávamos atravessando, nem de que forma essas mutações foram apropriadas pela população. As dosagens de choques cotidianos às quais fomos submetidos anestesiaram nossa sensibilidade sobre essas questões. De fato, basicamente, tivemos "boletins de guerra", com os números diários de novos contagiados e de mortos. Apesar de todas as sugestões midiáticas sobre "o tempo reencontrado" na fase do lockdown (outra narrativa bem presente, mas pouco inclusiva, considerando que alcançava somente a parcela de população que, efetivamente, se encontrou desautorizada para se deslocar até o lugar de trabalho), sobre a "grande chance" de mudar nossos hábitos familiares, o que dominou foi a construção de narrativas sobre um Estado de Guerra. Paralelamente à construção dessa narrativa, o Parlamento passou a ser dispensado das decisões em função da adoção do Estado de Emergência, durante o qual o Primeiro Ministro utiliza o instrumento dos decretos, eliminando, de fato, a necessidade de qualquer discussão entre deputados e senadores. Simplesmente, o Primeiro Ministro, assessorado por um comitê científico, passou a assinar as decisões sem discussão parlamentar. Quanto isso mudou a configuração de nosso entendimento do espaço público? Tornou-se muito difícil criar palavras quando, a cada momento, a mídia repetia até à exaustão que se tratava de uma emergência, impondo responsabilidades individuais para a sobrevivência da coletividade. Se tornaram frequentes as reações (todas digitais, remotas, que fique claro) em que, a qualquer dúvida, questionamento que fosse expressado, a resposta era, resumidamente, "isso não importa, estamos em uma emergência, pensar não faz parte 
do quadro, temos que obedecer". Quem questionou sobre o possível cenário, seja bélico, seja pós-bélico, passou, rapidamente, a ser visto como "inimigo" da saúde pública, inimigo de um coletivo cuja configuração, todavia, não era definida claramente, como se tratasse de um conceito óbvio, portanto sem necessidade de explicitar quem estava incluído nessa coletividade: de que coletivo estamos falando? Ele incluía somente os italianos? Incluía a população global? E os migrantes, eram parte desse coletivo? O que se observou foi que, nesse coletivo, não tinham rosto, nem palavras aqueles trabalhadores considerados necessários: os trabalhadores ligados à saúde e aqueles ligados à produção, tratamento, transporte e vendas de alimentos, bem como aqueles envolvidos em uma série de indústrias e serviços considerados de primeira necessidade. No decreto emitido no dia 11 de março, as atividades essenciais cobriam um leque bastante amplo, como pode ser observado:

a) Suspensão do Comércio no varejo, com a exclusão de gêneros alimentícios, tabacos, farmácias, bancas de jornais.

b) Suspensão de todos os serviços como bares, restaurantes, botecos, sorveterias.

c) Fechamento de serviços dedicados à pessoa (cabeleireiros, barbearias, centros estéticos).

d) Abertura, no respeito das normas higiênico sanitárias, de bancos, serviços financeiros em geral e, como dito antes, de todo o setor produtivo, de transformação e transporte agroalimentar.

e) Redução dos serviços de transporte público (trens, aviões e ônibus) (DPCM, 2020)

No tatear no escuro que o desconhecimento do futuro provocava, o Capitalismo Viral escolheu, poucas semanas depois, seu caminho de fingir que era possível isolar os corpos frágeis sem mudar os hábitos do sistema produtivo, baseando-se na necropolítica econômica, e voltando a reabrir outros setores (inclusive o de produção de armamentos), enquanto a população só podia se deslocar para fora de casa por razões de trabalho ou de saúde, desde que apresentasse justificativa em formulário, devidamente assinada, para os controles que as forças da ordem efetuavam nas ruas. $\mathrm{Na}$ falta de alternativas plausíveis, de visões divergentes, as instituições políticas e financeiras, através das mídias, utilizaram duas ferramentas. A primeira, através da implementação da linguagem de guerra, articulando a necessidade de sacrificar os corpos frágeis. Toda guerra tem vítimas, é inevitável, eles serão as vítimas dessa guerra. Tornou-se explícita a necessidade de mudar essa escolha discursiva de ferramentas ligadas à natureza de um estado de guerra. A segunda visão foi da estruturação da "energia positiva". Se pensarmos positivo, tudo vai dar certo. Essa linguagem se construiu oferecendo ao público uma série de notícias sobre como, apesar de tudo, a situação ia ser serenamente resolvida (como e quando, porém, sem prazos definidos).

Começaram a surgir pedidos para que o isolamento social fosse retirado. Em nome da economia do Capitalismo Viral, houve vozes sugerindo o isolamento "parcial" dos corpos idosos e doentes, o chamado "isolamento vertical". Esses corpos frágeis, na lógica perversa dessa falsa guerra, tornaram-se nossos inimigos, adquirindo, aos poucos, as feições de nossa morte social e econômica.

Que o Capitalismo Viral tenha se articulado para preencher o "vazio" provocado pela pandemia tornou-se patente na tipologia de notícias e polêmicas que invadiram a mídia. Uma virada no tom é representada pela afirmação de Stefano Bonaccini, presidente da Emília Romagna, convidado da transmissão Piazza Pulita (DI MARTINO, 2020): "Nós vamos encontrá-los casa por casa (os positivos)", que dá a ideia de um 
ataque e não mais do que uma guerra de posição. Uma frase que é lida (e difundida pela oposição) mais como um ataque aos cidadãos do que ao vírus, já na fase inicial, muito delicada, da reabertura. Na verdade, a declaração, relançada em jornais e redes sociais, é distorcida para enfatizar uma ameaça latente. "Ameaça de Bonaccini: 'Vamos encontrá-los de casa em casa!"” (LA PRESSA, 2020). As polêmicas, também, se voltaram contra aquela que foi uma escolha dura e, em muitos momentos autoritária e mal conduzida, da reclusão obrigatória para a Itália inteira. Os principais necroeconomistas insurgiram para convidar à contemplação do desastre que essa escolha provocou. Desastre que não apontava mais para a "viralidade" mortal, mas somente o "campo de batalha" que, por um breve momento, rechaçou alguns - poucos - aspectos cruéis do Capitalismo Viral. Quem nos inscreveu nos termos da necroeconomia esqueceu (voluntariamente?) que o problema nunca foi do vírus que apareceu matando indiscriminadamente. Artigos sobre (necro)economia começaram a mostrar como o lockdown fez uma única vítima, o "Mercado", pois, estatisticamente, a covid-19 não aumentou de maneira tão evidente, os números relativos à mortalidade. Números, esses, propostos como "gerais" em temporalidades diferentes. Os dados sempre foram claros: a covid-19 mata, sim, em maior percentagem do que uma gripe comum, porém mata principalmente idosos e corpos com patologias pregressas, mesmo que a grande maioria dos infectados tenha sarado e sare. Aquilo que (voluntariamente?) os defensores da necropolítica e da necroeconomia do Capitalismo Viral esqueceram é que o problema surgiu, desde o começo, perante a necessidade (necessidade, nunca vou repetir o suficiente, gerada "artificialmente" pela própria necroeconomia neoliberal) de terapia intensiva por parte de um número maior de corpos do que da disponibilidade de leitos, reduzidos drasticamente pelos cortes à saúde pública dos últimos vinte anos, pelo interesse em investir na renda do setor privado. As reclamações necroeconômicas sobre o lockdown mistificaram os fatos, em sua tentativa de demonstrar que essa decisão, que realmente sacrifica o Produto Interno Bruto (PIB) em favor dos corpos, de todos eles, não teve nada a ver com um aumento não marcante da mortalidade. Porque é verdade, esse aumento não é evidente quando observado no contexto de grandes números e de séries. Mesmo que seja perceptível, não é um aumento significativo. O que os necroeconomistas e os necropolíticos querem que esqueçamos a priori (voluntariamente?) é que o lockdown foi necessário porque, sem ele, um número muito maior de corpos morreria, pois não teriam a possibilidade de internar-se em UTIs. Dentro do paradoxo da renúncia (essa sim, voluntária) a uma série de direitos, ainda a ser amplamente refletida e discutida face o presente/futuro que projetamos, fundamentalmente o lockdown foi uma escolha ética "anti-nazifascista", pois observou-se a recusa em aceitar a seleção eugênica de eliminação (dita) "natural" dos corpos improdutivos, aqueles que têm somente um custo para a coletividade, sem produção de riqueza material - os dos idosos, os dos doentes crônicos e, em alguns lugares, como em certos estados dos EUA, chegando a propor o sacrifício de deficientes físicos e mentais na seleção para morrer, como noticiado pelo jornal diário da Conferência Episcopal Italiana, L'avvenire de 25 de março de 2020 (MOLINARI, 2020). Não podemos esquecer que, na Itália, a região mais flagelada pela covid-19 foi exatamente aquela propagandeada como "a mais produtiva", ou seja: a que mais adotou a receita neoliberal. Destacamos, portanto, a manipulação da memória dos fatos que, perante a tendência para uma reabertura total, voltou-se a favor desse novo Capitalismo Viral. Essa reabertura envolveu a economia industrial e do comércio, mas fez questão de deixar de fora, no silêncio mais ensurdecedor, os problemas ligados à produção de cultura (teatro, música, cinema...). Da mesma forma, a discussão sobre reabertura das escolas (de todos os graus) se colocou como grande incógnita. Tudo reabriu, mas as escolas não, no mínimo até 
setembro. Ou seja: a forma mais clara de exclusão social se disfarçou atrás da mentira de que todos teriam acesso aos recursos digitais. E, principalmente, que a sociabilidade que se constrói no mundo da escola pode ser, sem mais nem menos, eliminada em um golpe só, fingindo que isso não acarretará consequência nenhuma.

\section{RESPOSTAS FORTEMENTE AUTORITÁRIAS E “EXEMPLARES” SOBRE OS (POUCOS) CORPOS “REBELDES” ÀS RESTRIÇÕES}

Em termos quotidianos, em termos compreensíveis, como se identifica essa doutrina que o Capitalismo Viral estabeleceu? Acreditamos ser necessário entender através de exemplos.

Analisaremos duas imagens que se referem às "batalhas" conduzidas pelo controle do corpo durante a emergência: a biopolítica se observa aplicada de maneira contundente na forma de controle autoritário, desproporcional.

Durante o feriado da Páscoa, os "monstros" ganharam seu lugar nas páginas dos jornais. Monstros foram aqueles que, isolados em um mesmo prédio, mas não do mesmo núcleo familiar, resolveram fazer um churrasco no teto do condomínio. Traídos pelo cheiro da carne que assava, esses novos "pecadores" foram alvo de denúncias e de fiscalização policial. Monstro foi aquele corpo que, solitário, ousou se encontrar em uma praia deserta (BLITZ, 2020). A escolha não foi a de uma abordagem discreta de algum fiscal que, educadamente, pedisse para que voltasse para casa. Não, escolheuse o estrondo de um helicóptero que pairou por cima do corpo desobediente, antissocial em sua solidão. Todos viram a punição exemplar dessa "ameaça", levada a cabo pelo barulho metálico, repetido à exaustão no vídeo enaltecido pela mídia. Um corpo solitário que ganhou a reputação social de pecador. E outros episódios similares se repetiram. Rechaçar exemplarmente a "liberdade de churrasco", criminalizar espetacularmente o passeio solitário, a corrida esportiva se tornou a atividade privilegiada dos "rancorosos do tempo livre", essa espécie contaminada pela mutação moral do vírus. Os corpos que se tornaram exemplos negativos e sensacionais dessa guinada no sentido radical do pecado viral nada tem a ver com um efetivo controle da doença. Repito: abordagens não "espetaculares" sem destemidas manobras de barulhentos objetos voadores, não teriam alcançado a mídia, mesmo resolvendo o problema dos infratores, sem sequelas no imaginário "moral" da nova "polícia social" em que grande parte da população aparentemente passou a se identificar. A segunda imagem foi publicada pela Prefeitura de Rimini (COMUNE DI RIMINI, 2020). O vídeo a que pertence este quadro apareceu dia 17 de abril, às 13h29, na página do Facebook da Prefeitura da cidade, em uma postagem que alardeava, com certo orgulho e várias metáforas retoricamente enfáticas, o uso eficiente de "olhos voadores" (isso é: drones) na caça de transgressores da proibição de isolamento domiciliar. A narrativa que a imagem proporciona se desenrola de maneira clara: 0 "culpado" ainda é placidamente imerso no banho de sol, em posição de destaque na moldura, ligeiramente à direita do centro geométrico, sem saber o que está para lhe acontecer, enquanto os guardiões da ordem irrompem de baixo, com a poderosa simetria de suas figuras e seus "corcéis mecânicos" à espera.

A seleção dessa imagem não foi acidental: foi escolhida entre os muitos quadros possíveis do vídeo. Houve, portanto, uma edição não trivial, de modo a obter uma imagem que não é apenas documental, mas também esteticamente eficaz. Não estamos perante um simples "relatório" aos cidadãos, mas, sim, uma persuasiva imagem de propaganda. 
Ainda, o visual fornecido parece referir-se a imaginários significativos: a areia, um espaço sem direções em que se movem robocops uniformizados, remete às sagas bem presentes no imaginário de ficção científica, de Star Wars a Dune, onde a areia é a cenografia de um mundo reduzido ao seu grau zero de sobrevivência inóspita, o antagonista simétrico da tecnologia, enquanto o drone, voando sobre as tropas, evoca os helicópteros dos filmes do Vietnã. Imagens icônicas, em que todo e qualquer contexto desaparece, em favor de uma retórica visual de garantia da saúde pública. Pouco importa se, de repente (e ninguém sabe se foi isso, nem nunca saberá), se tratava de um trabalhador dedicado à limpeza da mesma praia, ou mais genericamente, de um qualquer trabalhador em um breve momento de descanso.

A emergência chegou de bandeja para aqueles países que "sofriam" movimentos/revoltas populares, clamando por maiores direitos (Hong-Kong, mas também os movimentos de rua no Chile, só para citar os que mais ocupavam as manchetes). Em geral, toda e qualquer manifestação que envolvia a presença "analógica" de corpos em revolta desapareceu. Não desapareceu, porém, em momento nenhum, - é sempre bom lembrar - o fluxo (também analógico, material, físico) das mercadorias e aquele - virtual, mas não por isso menos real - dos capitais. Não teve um único dia, em toda essa emergência, que tornou nossos corpos imateriais na esfera pública, que não soubéssemos sobre o andamento dos mercados e das bolsas de valores. A construção do medo, pelo sistema de informação capitalista, tornou-se aliada preciosa para implementar a "doutrina" do choque. Palavras e imagens utilizadas ao longo desse tempo todo geraram formas de terror apocalíptico.

Tratou-se de uma mutação de tipo moral do novo coronavírus, no melhor espírito do Capitalismo Viral. De fato, não possui qualquer relação com a preservação da saúde dos corpos, na medida em que a maioria das empresas produtivas que precisam da mão de obra presencial nunca pararam durante essa emergência sanitária. Os corpos produtivos, em sua maioria proletários, na hora do trabalho, não tiveram silenciada sua exposição ao risco. Ela foi transformada sublimemente em "sacrifício" necessário a ser (retoricamente, mas não economicamente) ressaltado como heroico na hora do trabalho. Mas quando esses mesmos corpos são detectados em seus momentos de "descanso", eis que se tornam "pecadores". Divertir-se é inaceitável. Sacrificar-se em nome do PIB é desejável. Mesmo que o risco representado por esses corpos para um "bem-estar" do coletivo nunca identificado claramente seja infinitamente menor: quem está sujeito à contaminação viral se um corpo passeia solitário na praia, se um corredor com sua mascarazinha atravessa a rua para cruzar com ninguém? Se a família ampliada de parte de um condomínio almoça junto no teto do prédio, sem se aproximar muito um do outro? O verdadeiro perigo passa a ser o contágio moral, incentivado pelas medidas tecnológicas e estrondosas utilizadas para reprimir, medidas amplificadas pela repetição das imagens impactantes de helicópteros ruidosos e operações "militares” nas mídias. Estabelecendo esse nível de imaginário da atuação das forças policiais, busca-se evitar que outros possam querer se apropriar do tempo do lazer. Apesar de todos saberem como se comportar, porque todos aprendemos as regras de base para evitar riscos à saúde, o gozo passou a ser vigiado e - possivelmente - punido de maneira exemplar. Quem discorda, ou desconfia de que não, não é para o nosso bem - entendido como o bem de "todos"- que uma série de mecanismos de controle que estabelecem novas biopolíticas - e necropolíticas - são colocados para funcionar, se torna o novo herege. Se, de um lado, é preciso, fundamental, certeiro acreditar no que a ciência nos diz, é também verdade que isso se transforma em uma crença que impede qualquer outra 
discussão ou debate. Incomoda, por exemplo, o fato de que havia uma emergência do que passamos a chamar de "tecno-ciência". Nos provocava desconfiança: não pelo seu método - rigorosamente científico - mas pelas suas finalidades. Havia reservas, sobre seu ser sujeita a um sistema de produção cruel - que não desapareceu, mas se tornou Capitalismo Viral. O medo, induzido em todos, não permite mais essas reservas. Tudo se tornou imposto por "comissões" e "grupos de vértice", cujos critérios de escolha não nos são dados conhecer. Essas formas de governança em ato não consideram em momento nenhum a possibilidade de participação mais ampla da população - porque a população não conhece, não tem instrumentos de compreensão, em breve, não é confiável. Portanto, essa população de corpos é, a priori, excluída das decisões. Governa-se pelo medo. "Medocracia" tornou-se a forma de governo do Capitalismo Viral. Medocracia é aquela forma de governo que vê positivamente o uso de álcool e tabaco como formas de controle nas casas em que somos reclusos (não é, portanto, de se estranhar que as tabacarias tenhas sido consideradas fornecedoras de bens essenciais durante o lockdown, podendo permanecer regularmente abertas), ou que vê positivamente a produção de pizzas e bolos e comida em quantidade, dentro de nossas residências. Por outro lado, a medocracia vê como postura lamentável quem corre na rua, quem pratica exercícios nos parques ou nas praias, mesmo sozinho e no mais profundo respeito das regras de distanciamento físico entre os corpos. A primeira etapa da mutação moral que se verificou foi, é claro, a imposição necessária do distanciamento corporal, que em termos linguísticos foi definido "distanciamento social". Vejam bem, as palavras têm peso: a distância dos corpos, que é física, se torna afastamento da empatia. De física a social, através de uma alquimia linguística banal, o passo foi bem curto. $O$ afastamento se tornou um fato social na medida em que provocou a desagregação de um sentir comum. $O$ "outro" é distante não somente como corpo, mas como entidade pensante. Sua presença, graças às metáforas bélicas, se tornou

inimiga.

Em um segundo momento, nos foi ensinado que os corpos que correm, mesmo distantes de nós, representam a desobediência, a "antissocialidade" doentia do egoísmo.

Quem discorda, ou desconfia de que não, não é para o nosso bem - entendido como o bem de "todos"- que uma série de mecanismos de controle que estabelecem novas biopolíticas (e necropolíticas) são colocados para funcionar - se torna o novo herege.

Se, de um lado, é preciso, fundamental, certeiro acreditar no que a ciência nos diz, é também verdade que isso, quando aplicado ao mundo social se transforma em uma crença que impede qualquer outra discussão ou debate. A política do medo pelo corpo, profano veículo de infecção, bem se implantou nas piores raízes cristãs da concepção do pecado e da punição. Os corpos, agora, são todos, potencialmente, impuros e contagiosos. Depois de anos de hedonismo e culto do corpo, de vida gourmetizada e de ideais de juventude eterna, de horror ao envelhecimento (e esse vírus privilegia a eliminação de corpos velhos e doentes, improdutivos) a covid-19 permitiu a revanche do moralismo mais radical. O que está acontecendo é uma "mutação" moral do contágio, moldada pela estrutura que a informação sobre a quarentena assumiu. Essa mutação é de tipo psicológico, é claro, e aparenta dar vazão à repressão corporal à qual somos submetidos há quase quarenta dias.

Essa nova austeridade "gileadiana" (a referência a O conto da aia, infelizmente, é quase espontânea) substituiu, com sua matriz moral, a austeridade de tipo científico, que sugere o distanciamento dos corpo, mas não se atreve a substanciar os efeitos sociais desse distanciamento. Não é papel da ciência julgar moralmente toda e qualquer atividade relacionada ao gozo dos corpos. Transformados em policiais morais, aqueles 
que podiam patrulhar as ruas, porque autorizados pela posse de um cachorro (intitulados a saírem a qualquer hora do dia pelas exigências fisiológicas do inocente animal, algo que nem às crianças foi permitido, crianças castradas de suas exigências fisiológicas), paravam para ouvir as vozes atrás dos muros. Vozes que, quando expressavam alguma forma de felicidade, quando acompanhadas de música, se tornavam inaceitáveis, mau exemplo, ameaça às regras da clausura. Vozes imediatamente denunciadas. Gilead, na ficção, não teria feito trabalho melhor. Na realidade, as milícias da Kabul dos talebãs, também, observam com admiração os resultados alcançados. O marasmo em que entramos deixou aflorar as contas malfeitas da injustiça social. Essas areias movediças, infâmias do capitalismo, desenharam os fantasmas da pobreza para muitos. O medo, porém, não pôde segurar o impulso da luta de classe que habita os corpos dos empobrecidos de maneira mais evidente a cada dia que passava. As discussões que circularam nos jornais giravam em torno de perdas e retomadas dos consumos, retomando a lógica pré-viral, desconsiderando alternativas plausíveis de outros modelos a serem elaborados. O capitalismo foi fiel à sua visão de "resiliência", pedindo que nossos corpos se sacrificassem para começar, novamente, a consumir mercadorias que, durante o lockdown, se revelaram tão supérfluas como as bicicletas para os peixes. Na nossa frente se colocaram duas escolhas: retomar o trilho do sistema do capitalismo, endurecido em sua face viral de eliminação dos corpos improdutivos e incapazes de consumir, ou desbastar novas veredas desconhecidas, em que os corpos vivos pudessem se tornar sujeitos. O Capitalismo Viral, no final das contas, só fez acelerar os processos de exclusão. Ele calculou que as perdas humanas da pandemia não eram destinadas a influenciar os consumos: continuou tendo sua reserva de mão de obra para substituir os corpos que caíram; continuou tendo consumidores famintos de mercadorias inúteis. Desde que aceitamos o "sacrifício" e reabrimos tudo, como se nada tivesse acontecido.

\section{A PROJEÇÃO DO FUTURO EM DUAS IMAGENS}

Outras duas imagens, bastante surreais e inquietantes, apareceram predizendo nosso futuro. Tratou-se de hipóteses biopolíticas para a economia "voltar a funcionar", que foram apresentadas à população com ampla repercussão. Na primeira imagem (na verdade, uma galeria fotográfica proposta pela página do telejornal Sky24 (SKY TG 24, 2020), se oferece uma solução para permitir que voltemos a "socializar" nos restaurantes: tantas "gaiolas" estilo "colóquio prisional" quantos corpos consumidores ocuparem o espaço.

E, é claro, nada de passar a garrafa de vinho ou o pão para o vizinho. A segunda imagem (SERLONI, 2020) é muito mais "perturbante" em termos de implementação da doutrina de choque do Capitalismo Viral (KLEIN, 2007). De fato, não aponta unicamente para o distanciamento social necessário para retomar o desempenho da economia do turismo nas praias. Aponta para pelo menos outros dois fatores. O primeiro é a aceleração da desigualdade social: para poder "alugar" o box, em circunstâncias que impõem uma redução dos corpos que podem frequentar a praia, é preciso pagar. Existe na Itália o conceito de "praia livre", onde cada um pode ir, levando seu próprio guarda-sol. Só que a redução dos espaços a pagamento, em função da dilatação do espaço suficiente para a presença "legitima" dos corpos, poderia tornar efetiva a doutrina do Capitalismo Viral, tornando necessário ampliar as licenças aos privados, aos empreendedores do turismo, para que seus negócios sejam rentáveis, ocupando as praias "livres" e reduzindo, assim, ainda mais, o acesso aos que não dispõem de recursos - por outro lado, ir à praia sem plexiglass, ir à praia "livre" (em 
todos os sentidos, do lugar e da nossa liberdade) é proposto, pelas imagens, como algo que pode ser punido - quem sabe, com helicópteros e drones e homem fardados. Isso traz, como consequência já experimentada, a impossibilidade de voltar atrás: uma vez confiada a praia aos privados, aos privados fica.

\section{CONSIDERAÇÕES (NÃO FINAIS)}

O mundo "novo" que nos espera se apresenta no horizonte como particularmente reforçado em seus pressupostos do Capitalismo Viral. Não vai ter, como alguns impenitentes idealistas chegaram a sonhar, uma mudança efetiva de paradigma, ou um sistema baseado em uma mudança no papel do consumo que leve a uma certa frugalidade e na redução do tempo de trabalho, um repensar seriamente sobre a impossibilidade de crescimento "infinito". Tudo isso, nos sonhos idealistas, poderia ser aliado a maiores investimentos em políticas públicas de educação, saúde e pesquisa. Nada disso está acontecendo, nem é destinado a acontecer. Muito pelo contrário. $O$ capitalismo A.C. (Antes da Covid-19) até corre o risco de ser uma versão "boazinha" do capitalismo D.C. (Depois da Covid-19), ou Capitalismo Viral. O princípio do capitalismo que, enquanto princípio, é dado como certo, ainda que ninguém o tenha demonstrado - é de que o crescimento ilimitado e sem qualquer vínculo não somente é possível, mas indispensável. Com base nesse dogma é possível acumulação, enquanto o valor adjunto é uma obrigação. O dogma fundante do capitalismo tem se tornado, no tempo, a "fronteira" de toda e qualquer manifestação lógica, econômica ou política: não existe qualquer possibilidade de formação discursiva capaz de derrubar tal fronteira.

Nesse sentido, o capitalismo D.C., que chamei de Capitalismo Viral, tem se alimentado, durante a pandemia, de uma crise estabelecida, em primeiro lugar, como sanitária, mas que logo tem assumido feições de crise social - e até de mutação do vírus em algo "Moral", através de respostas fortemente autoritárias e "exemplares" sobre os (poucos) corpos "rebeldes" às restrições. Como já escrevi, tivemos "ataques" estilo Apocalypse Now, de helicópteros derrotando indivíduos solitários e "ataques" de exércitos de drones, também, envolvendo um único corpo solitário, deitado em uma praia.

Imagens icônicas, em que todo e qualquer contexto desaparece, em favor de uma retórica visual de garantia da saúde pública. A construção do medo, pelo sistema de informação capitalista, tornou-se aliada preciosa para implementar a "doutrina" do choque. Palavras e imagens utilizadas ao longo desse tempo todo geraram formas de terror apocalíptico.

Poderiam ter sido diferentes? Sim, certamente sim, nenhuma formação discursiva é obrigatória. No lugar de formulações terroristas ou belicistas, no lugar de demonstrações de forças desproporcionais e velhacas contra corpos inermes, sempre pode ser escolhida uma maneira honesta de apresentar os fatos e as soluções possíveis. Mas escolhendo outras imagens, outras estéticas, a "doutrina do choque" custaria a ser realizada com tanta facilidade.

\section{REFERÊNCIAS}

AGAMBEN, G. Lo stato d'eccezione provocato da un'emergenza immotivata. II Manifesto, 26 fev. 2020. Disponível em <https://ilmanifesto.it/lo-stato-deccezioneprovocato-da-unemergenza-immotivata/>. Acesso em $10 \mathrm{dez} .2020$. 
AVVENIRE. Coronavirus Milano non si ferma: la campagna social contro la paura. Avvenire, 27 fev. 2020. Disponível em <https://www.avvenire.it/attualita/Pagine/coronavirus-milano-non-si-ferma-lo-spotdel-sindaco >. Acesso em 15 nov. 2020.

BAZZI, A. "Io, medico e mamma, nella mia doppia trincea contro il Covid”. Corriere della sera, 20 mai. 2020. Disponível em <https://www.corriere.it/buonenotizie/20_maggio_13/io-medico-mamma-mia-doppia-trincea-contro-covid-ce187edc942e-11ea-9026-oed4807eoa45.shtml>. Acesso em 15 nov. 2020.

BELLANTE, F. Miram, per ter mesi in trincea contro il virus. II Centro, 01 jun. 2020. Disponível em <https://www.ilcentro.it/pescara/miriam-per-tre-mesi-in-trincea-controil-virus-1.2442084>. Acesso em 15 nov. 2020.

BLITZ. Coronavirus Palermo, elicottero dei Carabinieri allontana um uomo dalla spiaggia. Blitz, 12 abr. 2020. Disponível em <https://www.blitzquotidiano.it/video/coronavirus-palermo-elicottero-carabinieri3173771/>. Acesso em 10 dez. 2020.

$\mathrm{BOCCl}, \mathrm{M}$. Lo specializzando: in trincea contro il virus per aiutare la mia città. La Repubblica, 22 mar. 2020. Disponível em $<$ https://rep.repubblica.it/pwa/intervista/2020/03/22/news/lo_specializzando_in_trince a_contro_il_virus_per_aiutare_la_mia_citta_-252024434/>. Acesso em 10 dez. 2020.

COMUNE DI RIMINI. Página facebook, 17 abr. 2020. Disponível em <https://www.facebook.com/comunedirimini/photos/pcb.10157365478823505/101573 65477578505/:type=3\&theater>. Acesso em 10 dez. 2020.

DI MARTINO, P. Fermate Bonaccini: "Scoviamo i positivi casa per casa e li isoliamo. La7, 16 mai. 2020. Disponível em <https://www.oltre.tv/fermate-bonaccini-scoviamopositivi-casa-video/>. Acesso em 10 dez. 2020.

DPCM, 11 de março de 2020. Disponível em <http://lavoro.gov.it/documenti-enorme/normative/Documents/2020/DPCM-11-marzo-2020.pdf >. Acesso em $10 \mathrm{dez}$. 2020.

DURAND, G. L'immaginazione simbolica. Milano: Ipoc, 2012.

FIORI, S. Sassoon: “Marx ha finito le risposte”. La Repubblica, 11 ago. 2020. Disponível em:

<https://rep.repubblica.it/pwa/robinson/2020/08/11/news/donald_sassoon_marx_ha_f inito_le_risposte_-264420635/>. Acesso em $10 \mathrm{dez} .2020$.

FOUCAULT, M. (2020). Bisogna difendere la società - corsi al college de France (19751976). Milano: Feltrinelli, 2020.

IL GIORNO. Due mesi in trincea contro il virus. II Giorno, 06 mai. 2020. Disponível em $<$ https://www.ilgiorno.it/milano/cronaca/due-mesi-in-trincea-contro-il-virus1.5136862>. Acesso em 15 nov. 2020.

IL SECOLO XIX. In trincea contro il virus: ecco gli eroi silenziosi che combattono il contagio e la paura. II Secolo XIX, 06 mar. 2020. Disponível em <https://www.ilsecoloxix.it/genova/2020/03/06/news/in-trincea-contro-il-virus-ecco- 
gli-eroi-silenziosi-che-combattono-il-contagio-e-la-paura-1.38558221>. Acesso em 15 nov. 2020.

IMARISIO, M. Coronavirus, il medico di Bergamo: "Negli ospedali siamo come in guerra. A tutti dico: state a casa”. Corriere della sera, 20 mar. 2020. Disponível em <https://www.corriere.it/cronache/20_marzo_09/coronavirus-scegliamo-chi-curarechi-no-come-ogni-guerra-196f7d34-617d-11ea-8f33-90c941afof23.shtml>. Acesso em 15 nov. 2020.

INVIATO, R. A. Brescia resta in trincea contro il virus, aperto un nuovo reparto con 180 posti. 04 abr. 2020. La7, 04 abr. 2020. Disponível em <https://tg.la7.it/cronaca/bresciaresta-in-trincea-contro-il-virus-aperto-un-nuovo-reparto-con-180-posti-04-04-2020148758>. Acesso em 15 nov. 2020.

ITALIANO, P. Medici disarmati in trincera: "Così diffondiamo il virus". La Stampa, 20 mar. 2020. Disponível em <https://www.lastampa.it/alessandria/2020/03/20/news/medici-disarmati-in-trinceacosi-diffondiamo-il-virus-1.38613695>. Acesso em 15 nov. 2020.

KLEIN, N. Shock economy: l'ascesa del capitalismo dei disastri. Milano: RCS, 2007.

LA PRESSA. La Minaccia di Bonaccini: “Vi scovismo casa per casa!". La Pressa, 17 mai. 2020. Disponível em <https://www.lapressa.it/rubriche/le_vignette_di_paride/laminaccia-di-bonaccini-vi-scoviamo-casa-per-casa>. Acesso em 10 dez. 2020.

LA7. Brescia resta in trincea contro il virus. Aperto un nuovo reparto con 180 letti. La7, 04 abr. 2020. Disponível em <https://tg.la7.it/cronaca/brescia-resta-in-trincea-contro-ilvirus-aperto-un-nuovo-reparto-con-180-posti-04-04-2020-148758>. Acesso em $10 \mathrm{dez}$. 2020.

LAI, F. Coronavirus, rianimatori in trincea: "Se va avanti così, difficile curare tutti". La Stampa, 21 mar. 2020. Disponível em $<$ https://www.lastampa.it/torino/2020/03/21/news/coronavirus-rianimatori-in-trincease-va-avanti-cosi-difficile-curare-tutti-1.38619543>. Acesso em 15 nov. 2020.

LE GOFF, J. L'immaginario medievale. Milano: Mondadori, 1993.

MBEMBE, A. Necropolítica: biopoder, soberania, estado de exceção, política da morte. São Paulo: $\mathrm{n}-1$ edições, 2018.

MENEGANZIN, A. Coronavirus: quando l'emergenza promuove una nuova cultura della ricerca. Micromega, n. 4, 2020. Disponível em <http://lameladinewtonmicromega.blogautore.espresso.repubblica.it/2020/03/11/coronavirus-quandol'emergenza-sanitaria-promuove-una-nuova-cultura-della-ricerca/>. Acesso em 15 nov. 2020.

MOLINARI, E. Virus Usa, “Niente respiratori per i disabili”. Più di 10 Stati scelgono chi salvare. Avvenire, 25 mar. 2020. Disponível em <https://www.google.com/url?client=internal-elementcse\&cx=000889264977490495488:tlo1uu_t2i4\&q=https://www.avvenire.it/mondo/pa gine/niente-respiratori-per-i-disabili-pi-di-10-stati-scelgono-chisalvare\&sa=U\&ved=2ahUKEwj5yfill8btAhWGqaQKHeXEAzQQFjAFegQIBRAB\&usg=A OvVaw23CuBS56pfVpZBtqN2NaxG>. Acesso em 10 dez. 2020. 
MUOLLO, G. Gli specializzandi in trincea contro il virus: "Non chiamateci eroi, la paura diventa coraggio e amore". Cesena Today, 24 abr. 2020. Disponível em $<$ https://www.cesenatoday.it/cronaca/gli-specializzandi-in-trincea-contro-il-virus-nonchiamateci-eroi-la-paura-diventa-coraggio-e-amore.html>. Acesso em 15 nov. 2020.

PEGGIO, M. Farmacisti in trincea: "Anche noi esausto, ma non possiamo abbassare la guardia”. La Stampa, 06 abr. 2020. Disponível em <https://www.lastampa.it/topnews/primo-piano/2020/04/06/news/coronavirusfarmacisti-in-trincea-anche-noi-esausti-ma-non-possiamo-abbassare-la-guardia1.38686192>. Acesso em 15 nov. 2020.

SERLONI, L. Coronavirus, box in plexiglass tra gli ombrelloni: "Così garantiamo la sicurezza ma facciamo ripartire il paese". La Repubblica, 14 abr. 2020. Disponível em <https://www.repubblica.it/cronaca/2020/04/14/news/coronavirus_box_in_plexiglass tra_i_lettini_sulla_spiaggia_cosi_garantiamo_la_sicurezza_ma_facciamo_ripartire_il_ paese_-253958190/>. Acesso em 10 dez. 2020.

SKYTG24. Coronavirus, dai ristorante ai drive-in: le nuove abitudini dopo la pandemia. Sky TG 24 Disponível em <https://tg24.sky.it/mondo/2020/05/22/coronavirus-pandemiacovid-19-abitudini\#00>. Acesso em 10 dez. 2020.

VON HAYEK, F. La società libera. Soveria Mannelli: Rubettino, 1960. 